\title{
AISバイナリメッセージを用いた見張り情報の共有
}

松本 洋平 $^{1}$

\section{Sharing Watchkeeping Information using AIS Application Specific Message}

\section{Yohei MATSUMOTO}

\begin{abstract}
As an application of the ASM (Application Specific Message) of AIS (Automatic Identification System), which is so called "binary message", The author developed a system which shares information of the targets tracked by ARPA(Automatic Rader Plotting Aid) with other ships and boats equipped with AIS receivers. The system transmits two types of position data; one is absolute positions and the other is relative positions to the tracker. In 2013, for both data types, the accuracy of the tracked positions was evaluated at Tateyama comparing with the GPS data of a boat under tracking, and this paper reports the result.
\end{abstract}

Keywords : AIS, ASM, Binary message, Radar, ARPA

キーワード: AIS, ASM, バイナリメッセージ, レーダー, ARPA

\section{1. はじめに}

現在 AIS は搭載義務船に限らず、多くの船舶に搭 載されており、航海の安全、あるいは、港湾の安全 に役立っている。通信トラフィックの混雑に伴い次 世代 AIS の仕様が検討されてきたが、これは IMO (International Maritime Organization)に受理 されず、現在 IALA (International Association of Lighthouse Authorities)および ITU (International Telecommunication Union) では VDES(VHF Data Exchange System)として現行のAIS を含むより一般 的なデータ交換システムへ発展させる検討が行われ ている。

VDES の中にはバイナリメッセージ用の追加の通 信チャネルの設定も想定されており ${ }^{(1)}$ 、その実現を 確かにするためにはバイナリメッセージの応用に関 するさらなる研究を行う必要がある。

AIS バイナリメッセージは任意のデータを送信可 能なメッセージである。「バイナリ」という名称は適 切ではないとする向きもあり、しばしば、ASM
(Application Specific Message) と記されるが、本 稿ではバイナリメッセージで記述を統一することと する。

本研究ではバイナリメッセージの応用のひとつ として「見張り情報の共有」を挙げ、その実際的な システムを模索し試作した。

船間で見張り情報を共有することは海上交通の 安全に役立つと考えられ、過去、見張り情報の共有 を目的とした船間通信の研究が本学会でもいくつか 報告されている(2)-(5)が、それらは通信手段として無 線 LAN や携帯電話網を用いており、本研究はAIS バ イナリメッセージを用いているという点で異なる。

また、本研究は ARPA で追尾している船舶の情報 を自動的に共有する仕組みを提供しており、これも 新しい試みである。さらに、追尾する船舶の情報を 送信する方式として、1)絶対座標送信と 2) 相対座標 送信の 2 種類の方法を考案・実装している。

本稿では 2013 年度に館山湾において開発したシ ステムを 3 度試験し収集したデータについて報告す

\footnotetext{
1 正会員 東京海洋大学海洋工学部 （干135-8533 東京都江東区越中島 2-1-6） matumoto@kaiyodai. ac.jp
} 
る。

2 章でAIS バイナリメッセージを用いた見張り情 報の共有について、本研究で実現しょうとしている システムの海上交通における有用性を説明する。3 章では見張り情報の共有に関する過去の研究を紹介 する。4 章では現状の AIS バイナリメッセージにつ いて解説し、5 章で今回作成した情報共有システム について説明する。6 章で実験結果を示し、7 章でま とめる。

\section{AIS パイナリメッセージを用いた見張 り情報の共有}

海上保安庁が平成 26 年 3 月 19 日に発行した「海

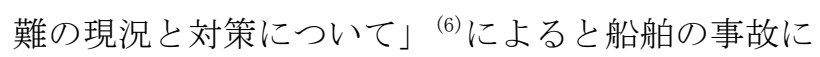
おいて衝突が $29 \%$ て最も多く、事故原因としては見 張り不十分が $21 \%$ て最も多い。事故を起こした船種 としてはプレジャーボートが最も多く $42 \%$ 、次いで 漁船が多く $31 \%$ であ、概して小型船舶による事故 が衝突事故の大半を占めていると言える。そこで、 本研究は主として小型船舶の衝突事故を抑止するこ とを目的としたい。

通常、小型船舶には AIS 搭載義務がなく、それら の AIS 非搭載船舶は目視かレーダーによる見張りに よって発見しなくてはならないが、小型船舶は小さ いため基本的に発見することが難しい。近年、小型 船舶向けの AIS トランスポンダとしてクラス B AIS が存在するが、その設置には数十万円の出費が必要 であり、また、送信間隔も長いことから、急速な運 動を行う小型船舶に適した装備であるとは必ずしも 思われない。また、小型船舶は十分な見張り人員や 見張りのための装備 (レーダーやAIS 受信機)を備え ていないことがある。したがって、見張る側として も、見張られる側としても小型船舶に関しては困難 があり、事故の危険性が多いと考えられる。

そこで、レーダーや十分な人員による高度な見張 り能力を有するVTS(Vessel Traffic Service)やク ラス A AIS 搭載船舶（以下、見張り局）から AIS 非 搭載船舶を捕捉し、その航行情報を AIS バイナリメ ッセージとして放送して船舶間で共有すれば、小型 船舶における見張り能力を強化することができると 考えられる。これによれば、AIS 非搭載船舶であっ ても安価な送信機能を持たないAIS 受信機を装備す れば、放送された情報によって周辺の AIS 非搭載船 舶を含む船舶の動静を知ることができるようになる。 文献 ${ }^{(7)}$ にはAIS 受信機を用いた小型船舶用見張り支
援システムに関して検討が行われている。

また、近年、東京湾においては海上交通センター が管理するレーダー局に高性能な半導体レーダー (8), (9) が導入されつつあるが2、そのような高性能なレ ーダーを備えた見張り局が AIS バイナリメッセージ を用いて捕捉した船舶の情報を放送すれば、小型船 舶に限らず、周囲の船舶は安価な装備でそれらの恩 恵を受けることができる。

あるいは、著者は目視による見張りを代替するコ ンピュータビジョンシステムの研究を行っているが、 その初期的な研究では非常に高解像度なカメラが多 数必要であること、それに伴って、非常に高性能な 計算機が必要であることが問題となっている ${ }^{(10)}$ 。 これに関しても、見張り情報を共有することが可能 であれば、全ての船舶に搭載する必要性がなくなり、 実現性を若干なりと向上させることができると期待 している。

さらに進んで、コンピュータビジョンやレーダー 信号処理システムが船舶を自動捕捉する際に、補助 となる情報を複数の見張り局で共有することができ れば、目標の自動捕捉をより高精度にできるように なると考えられるが、これは本稿の範疇とはしない。

\section{3. 船間情報共有に関する過去の研究}

過去に船間の情報共有に関しては本学会でいく つか研究報告がなされている。

船舶間で見張り情報を共有することで船舶運航 の安全性を高める試みが文献 (2), (3) に示されている。 文献 ${ }^{(2),(3)}$ では通信手段として IEEE802.11Jを用いる 前提で海上浮遊物や海洋生物等の情報を接近した船 舶間で共有するシステムの可能性を検討している。

また、文献 ${ }^{(4),(5)}$ では当該文献の著者らが構築した ユビキタスナビ (IEEE 802. 11J および $3 \mathrm{G}$ 回線に基づ く小型船舶の航行情報を共有するためのネットワー ク)を用いて、ユビキタスナビ搭載小型船舶 (漁船) の情報を収集し、ユビキタスナビ搭載船舶に配信・ 共有するシステムを作成し水産業における活用を示 している。

船間で通信を行う方法としては、本研究で取り扱 うAIS バイナリメッセージの他に、上記の研究で使 われている IEEE802.11J等の無線LANや携帯電話網、

\footnotetext{
2 海上交通センターの $14 \mathrm{GHz}$ 帯レーダーや $3 \mathrm{GHz}$ 帯 レーダーは実用されている。9GHz 帯レーダーに関 しては IMO 性能基準や電波法を満たすか否か検討 が行われている。
} 
Table 1 Summary of Binary Message

\begin{tabular}{|l|l|l|l|}
\hline Type & Destination & length & TDMA \\
\hline 6 & Addressed & 920 & RATDMA \\
\hline 8 & Broadcast & 952 & RATDMA \\
\hline 25 & Broadcast & 128 & RATDMA \\
\hline 26 & $\begin{array}{l}\text { Addressed/ } \\
\text { Broadcast }\end{array}$ & 1064 & SOTDMA \\
\hline
\end{tabular}

衛星通信が考えられる。

無線 LAN は数 Mbps と高速であるが、通信距離が 数 $\mathrm{km}$ 程度と短い。携帯電話網は数十 Mbps と高速で ありまた基地局から数十 $\mathrm{km}$ の範囲で通信可能であ るが、そのサービスは基本的に沿岸域に限られ、ま た、通信料金を生じる。衛星通信は、通信速度は最 大 $1 \mathrm{Mbps}$ 程度でサービス範囲は広大であるが、非常 に高い通信料金を生じる。

それらに対して、AIS バイナリメッセージを用い る方法の利点は、 (a) 世界的に成立している既存のイ ンフラを活用できること、(b)陸から離れても船舶に 搭載された設備だけで通信ができること、(c) 通信距 離が数十 $\mathrm{km}$ ときわめて長いことが挙げられる。

欠点としては通信速度が最大 $9600 \mathrm{bps}$ と極めて遅 い点が挙げられる。この欠点は将来のAIS の拡張に 期待することもできるが、基本的に見張りに必要な 情報を厳選して送信することで回避できるものと考 える。ただし、文献 ${ }^{(4),(5)}$ のような用途に関しては、 見張り局を用意する必要があり逆に高コストで向か ないと思われる。

\section{AIS バイナリメッセージ}

\section{1 パイナリメッセージの種類}

バイナリメッセージに関して本研究を理解する 上での基礎となる記述を文献 ${ }^{(11)} よ り$ 抜粋して以下 に記す。

現在 AIS バイナリメッセージは AIS メッセージタ イプ $6,8,12,14,25,26$ として合計 6 種定義さ れている。このなかで、タイプ 12 と 14 は安全に関 するメッセージを送信するということになっている が、それぞれ、形式としてはタイプ 6 と 8 と同じで あり、ここでは扱わない。Table. 1 にバイナリメッ セージの概要をまとめる。

タイプ 6 はアドレス付きバイナリメッセージであ り、送信先を指定できる。タイプ 8、25 はブロード キャストバイナリメッセージであり、全ての船舶に 対して送信する。タイプ 26 はアドレスド付き・ブロ ードキャストの双方の設定ができる。ブロードキャ
ストバイナリメッセージと同じく、アドレス付きバ イナリメッセージも基本的に全船舶に対して送信さ れる。アドレス付きバイナリメッセージがブロード キャストバイナリメッセージと異なるのは受信側で そのメッセージが自分宛てであるかどうかを判断で きる情報が組み込まれているという点である。

タイプ 6 は最大 920 ビット、タイプ 8 は最大 952 ビットの任意のデータを送信することが可能である。 また、タイプ 25 は 128 ビット、タイプ 26 は最大 1064 ビットのデータを 1 つのメッセージで送信すること が可能である。タイプ 25 のタイプ 8 に対する利点は 1 スロットしか送らない場合には、余分な情報を送 らずに済むことである。

データの内容については、メッセージに含まれる DAC (Designated Area Code) と FI (Function ID)の組 で識別され、既に IMO や各地域で数多くの DAC と FI の組に関して様々なデータフォーマットが定められ ている。これについては 4.2 節で紹介する。

また、タイプ 6、8、25 のメッセージは RATDMA (Random TDMA)、タイプ 26 のメッセージは SOTDMA (Self Organaized TDMA) で送信されることに なっている。

AIS トランスポンダにおいて RATDMA でのメッセー ジの送信は、その送信要求を受け付けてから 150 ス ロット以内に行われる。AIS の通信フレームは 1 分 で、2250 スロットに分割されているから、150 スロ ットは丁度 4 秒になる。したがって、メッセージが 送信されるまでには最大 4 秒のタイムラグが存在す る。送信の決定はメッセージのプライオリティや送 信状況を考慮した上でランダムに行われるため、必 ずしも送信されるとは限らない。

また、メッセージ 6、8 の送信では、1 フレームに 送信できるスロット数が最大 20 に制限されている ことに注意が必要である。実験を行うまではこの仕 様を理解していなかったため、実験データは少々不 格好な結果となっている。これについては 6 章にて 詳述する。

SOTDMA は一定時間間隔で繰り返しスロットを利 用できるように予約するため、連続して複数のメッ セージを送る場合に適している。AIS で最も主要な 役割を果たしているメッセージタイプ 1 (動的情報) もこの方式で送られている。

繰り返し情報を送信する今回の研究の目的から すると、タイプ 26 の利用が適していると考えられる が、使用した AIS トランスポンダが対応していなか 
ったため、用いることができなかった。

なお、タイプ 12、14 を除くバイナリメッセージ の送信時の優先度は最低に設定されているため、他 のメッセージで通信トラフィックが混雑する状況で は送信可能性が優位に低下することになる。したが って、今回提案するシステムをそのまま応用するこ とは、信頼性の面で考えられないが本研究の目標は あくまでも提案するシステムの有用性を調べること にあり、必ずしも当該システムの実現まで現状のバ イナリメッセージの枠組みの中で行う必要性を主張 するものではない。最終的に当該システムは、AIS の通常のメッセージタイプとして実現してもよいし、 より優先度の高いバイナリメッセージが設定された 上でバイナリメッセージとして実現してもよい。

\section{2 パイナリメッセージの活用と開発}

バイナリメッセージの現在の活用としては、IMO で国際的に利用することが承認されているものと、 ローカルに承認されているものが存在する。

IMO に承認されているものについては文献(12), (13) に記されている。例えば気象海象の報告、海上交通・ 輸送の整理、船舶に関する追加の静的情報、仮想航 路標識等のバイナリメッセージが定義されている。 これらのメッセージの開発と試験に関しては文献 (14)にバルチック AIS 試験プロジェクト (AISBALTIC) における取組が報告されている。

また、地域ごとにはより特徴的なメッセージが定 義されている。現在開発が試みられているもので、 本研究に類似する目的のものとしては、アメリカ合 衆国において開発されているクジラと船舶との衝突 を回避するためのバイナリメッセージがある(15)。こ の開発は RAP(Right whale AIS Project)と呼ばれ る計画において開発が進められていて、ハイドロフ オンを搭載したブイによってクジラの鳴き声を探知 し、これを通信衛星経由で地上局へ送信した後に、 クジラの活動範囲を配信するために AIS バイナリメ ッセージを用いる。日本においても離島への主要な 交通手段である水中翼船がクジラに衝突する事故が 問題となっており、こうしたシステムには一考の価 值があるものと思われる。このシステムにおいては メッセージタイプ 8 を用い、DAC はアメリカ合衆国 の 366、FI は 34 と定めている。

ところで、文献 ${ }^{(12)}$ はバイナリメッセージの利用に 関してVHF データリンク層に負荷がかかり AIS 本来 の機能を妨げる懸念を示しており、例えば、文献 ${ }^{(12)}$

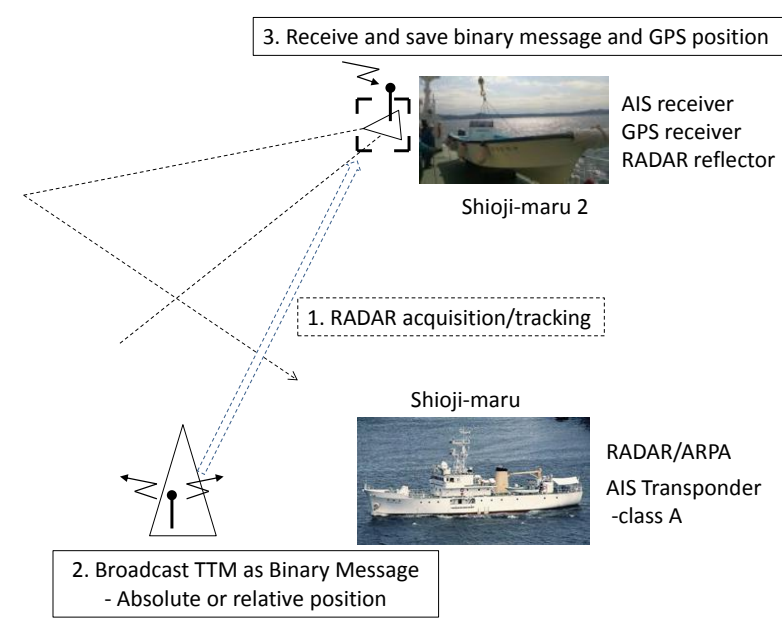

Fig.1 Experimental setup.

において試験運用に選ばれたメッセージの使用スロ ット数は 3 スロット以内とされている。本研究にお けるバイナリメッセージの利用は、高頻度に捕捉し た船舶の情報を送信するため、AIS のネットワーク に高い負荷をかける。これに関しては、必要最小限 の送信頻度と送信内容について検討していく必要が あると考えられるが、同時に、その利用法の有用性 に応じて、AIS に拡張が施されることを期待するも のでもある。

\section{5. 実証試験の準備}

実験では見張り情報共有実験として、実際にクラ ス A AIS トランスポンダを備えた船舶を見張り局と して、この見張り局から ARPA で捕捉した小型船舶の 位置情報をAIS バイナリメッセージとして放送し、 AIS 受信機を備えた小型船舶でこれを受信し、その 情報の精度について調べる。

Fig. 1 に実験の概略図を示す。

\section{1 船舶 · 海域の設定}

見張り局としては東京海洋大学の練習船・汐路丸、 見張り対象としては搭載艇・汐路丸 2 号を用いた。 汐路丸 2 号は AIS・GPS 受信機とレーダーリフレクタ を搭載し、汐路丸の前方 1 マイル以内を速度 $7 \mathrm{kts}$ で走行した。汐路丸は、錯を入れず、また係留もせ ず、自力で船首方位を維持したまま静止し、汐路丸 2 号をARPA で捕捉しその位置・速度を 4.3 節に説明 した方法でバイナリメッセージとして送信した。送 信したバイナリメッセージはその他の AIS メッセー ジ及び GPS データとともに汐路丸 2 号に搭載したコ ンピュータに保存した。これによって、GPS データ によって得られる汐路丸 2 号の実際の航跡とバイナ 


\begin{tabular}{|c|c|c|c|c|c|}
\hline \multicolumn{6}{|c|}{ - Absolute Position Data (85bit) } \\
\hline 8 bit & $12 \mathrm{bit}$ & 10bit & \multicolumn{2}{|c|}{ 28bit } & $27 \mathrm{bit}$ \\
\hline ID & COG & SOG & \multicolumn{2}{|c|}{ Longitude } & Latitude \\
\hline \multicolumn{6}{|c|}{ - Relative Position Data (52bit) } \\
\hline 8bit & 12bit & 10bit & 12bit & 10bit & \\
\hline ID & COG & SOG & Bearing & Distance & \\
\hline
\end{tabular}

Fig.2 Bit layout for absolute and relative position data.

リメッセージによって得られる汐路丸から送られて きた汐路丸 2 号の航跡を比較することができる。

実験は館山湾にて 2013 年 10 月 17 日、2014 年 1 月 21 日、3 月 6 日に実施したが、2013 年 10 月 17 日、及び、2014 年 3 月 6 日の実験では GPS データを 取得できなかった 3 ため、実質 2014 年 1 月 21 日しか 成功していない。今回は 2014 年 1 月 21 日のデータ について報告する。

\section{2 小型船舶の捕捉方法}

ARPA で船舶を捕捉するには、自動、あるいは、手 動の 2 通りの方法が考えられる。手動捕捉は ARPA 上でユーザーがカーソルを目標のレーダーエコーに 重ねて捕捉ボタンを押すことで行う。自動捕捉では ARPA が船舶のエコーであると判断したものを自動 的に捕捉する。自動捕捉は精度が低いので、今回は 手動捕捉を行った。

船舶の捕捉方法としてはARPA 以外にも、例えば、 コンピュータビジョンを用いる方法や (7)、ARPA とコ ンピュータビジョンを複合的に用いる方法が考えら れる。これは現在開発中である。

\section{3 バイナリメッセージの送信}

バイナリメッセージはタイプ８で送信する。タイ プ 6 はヘッダー情報が大きく、また、新たに定義さ れているタイプ 25、26 は現状の汐路丸搭載の AIS トランスポンダからは発信できなかったためである。 ARPA からは捕捉した船舶の本船からの方位と距 離が TTM(Tracked Target Message) センテンスで得 られる。これを AIS トランスポンダに BBM(Binary Broadcast Message) センテンスとして与えることで タイプ 8 が送信される。なお、本研究では TTM の中

3 どの日も 2 種類の GPS 受信機を用意して臨んだが、 館山湾ではしばしば GPS の電波を受信できない。 原因は不明である。なお、現在、汐路丸の GPS 受信 機は換装され、浦安沖で行った最近の実験ではこの 現象は起きていない。
でもステータスがトラッキング状態を示しているデ ータのみを送信することとしている。

送信方法としては二種類を試した。ひとつは絶対 座標送信、もうひとつは相対座標送信である。Fig. 2 に絶対座標送信・相対座標送信データのビットレイ アウトを示す。

絶対座標の送信では実験用 PCが TTMセンテンスを 得た時点での本船の GPS 位置を基準に計算した緯度 経度、TTM から得られる SOG (Speed over Ground)、 COG (Course over Ground)、TTM の識別番号を送信寸 る。データのビットレイアウトはタイプ 1 メッセー ジ(動的情報)の方式に従って、緯度 27bit、経度 28bit、COG 12bit、SOG 10bit とした。加えて識別 番号を $8 \mathrm{bit}$ としたので、合計 $85 \mathrm{bit}$ 送信することに なる。

相対座標の送信では TTM センテンスの内容から識 別番号、方位、距離、SOG、COG をそれぞれ8bit、12bit、 10bit、10bit、12bit で送信する。したがって、合 計 52bit 送信することになる。

相対座標送信の場合、受信側では見張り局の MMSI (Maritime Mobile Service Identity) 番号に対 応するタイプ 1 メッセージを使って絶対座標を計算 する。見張り局は、常にAIS トランスポンダの通常 の機能として自身の絶対座標等の動的情報をタイプ 1メッセージの形式で発信しており、これに加えて、 トラッキング対象の船舶の自船から見た相対位置情 報をタイプ 8 メッセージに詰めて送信する。受信側 は、その双方のメッセージを受け取ることで、見張 り局の絶対位置、見張り局に対するトラッキング対 象の船舶の相対位置を知り、よって、トラッキング 対象の船舶の絶対位置を計算することができる。

いずれの場合にも最終的にはトラッキング対象 の船舶に対して絶対座標が計算されるが、絶対座標 送信では見張り局において、相対座標送信では受信 局において絶対座標の計算が行われるという点に注 意されたい。絶対座標送信ではARPA から TTM を得た 瞬間の GPS 位置を使ってトラッキング対象の絶対座 標を計算するのに対し、相対座標送信では見張り局 の ARPA で生じた TTM の情報 (相対位置情報) を受信 局が受け取って、最近受信したタイプ 1 メッセージ による見張り局の絶対座標を元にトラッキング対象 の絶対座標を計算する。したがって、相対座標送信 では、相対位置情報と見張り局の位置情報の生じた 時間に最大約 14 秒(バイナリメッセージ送信遅延 4 秒+タイプ 1 メッセージの送信間隔 10 秒)の差が生 


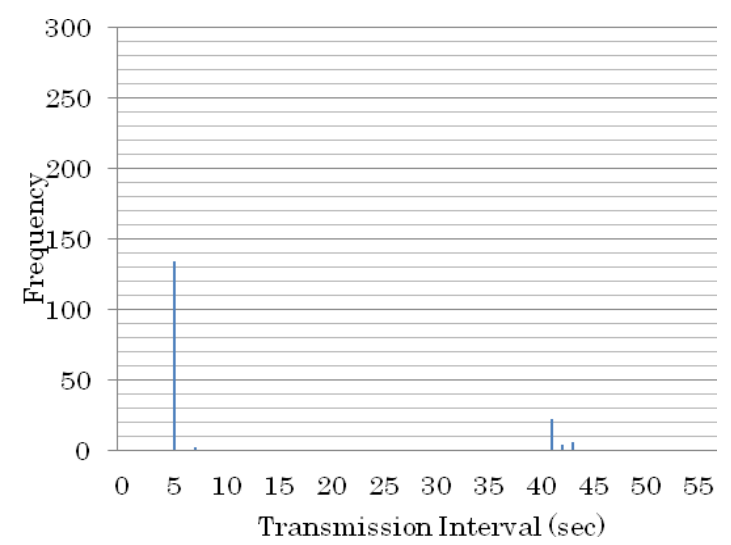

Fig.3 Histogram of the transmission interval for the absolute position transmissions.

\section{じうる。}

絶対座標送信はデータ量が多いが、TTM を得て絶 対座標を計算するまでの時間差が少ないため、見張 り局の運動による誤差が生じにくいと考えられる。 ところで、バイナリメッセージは、ビットスタッフ イング次第ではあるが、基本的に 1 スロットで 136bitの長さしか送ることができない(11)。諸々のへ ッダー情報を除くと 136bit のうちデータを送信す ることができるのは79bitである。したがって、相 対座標送信は 1 スロットで送信可能であるが、絶対 座標送信は 2 スロットでの送信になる。6.1 節で示 すが、使用スロット数は絶対座標送信と相対座標送 信の送信可能頻度に大きな差を生じる。送信頻度を 増やすことができるという点では、相対座標送信の 方が滑らかなトラッキングを実現しうる。

\section{6. 実験結果}

\section{1 パイナリメッセージの送信状況}

汐路丸 2 号を汐路丸のレーダーで捕捉して以降、 バイナリメッセージは 5 秒間に 1 回、チャンネル A・ $\mathrm{B}^{4}$ の両方に送信するようにした。絶対座標送信の実 験は 14 時 6 分 48 秒から 14 時 23 分 38 秒 (1010 秒) の間で、相対座標送信の実験は 14 時 24 分 19 秒から 14 時 41 分 13 秒 (1014 秒) まで行った。その結果、絶 対座標送信では 170 回、相対座標送信では330回の データを送信することに成功した。相対座標送信の 方の送信成功回数が倍近く多いのは、主に使用スロ ット数が半分と少ないためである。

\footnotetext{
${ }^{4}$ 通信の確実性のために 2 つのチャンネルに多重に 送っている。チャンネル A は 161.975Mhz (87B)、チ ヤンネル B は $162.025 \mathrm{Mhz}$ (88B)である。
}

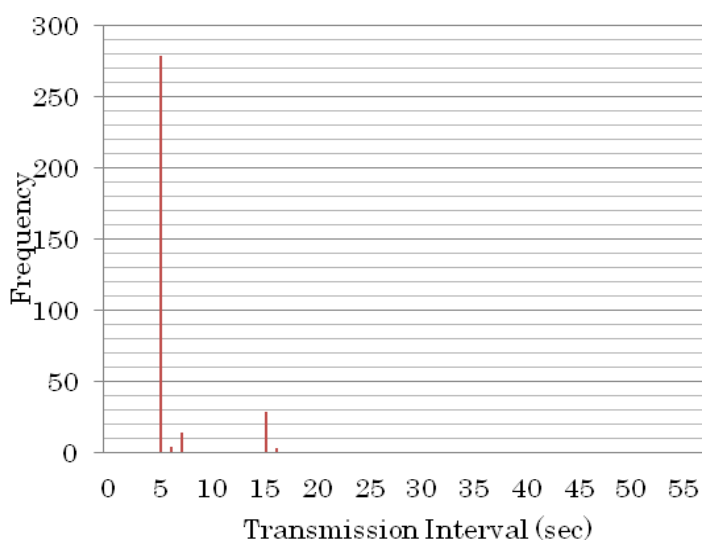

Fig.4 Histogram of the transmission interval for the relative position transmissios.

送信間隔を 5 秒と決めたのは、 $7 \mathrm{kt}$ の場合の AIS タイプ 1 メッセージの送信間隔が 10 秒であり、これ が $7 \mathrm{kt}$ の船舶をトラッキングするために妥当な送信 間隔であると想定して、さらに RATDMA が最大 4 秒遅 れることを考慮すると、5秒で送信すれば 10 秒以内 に確実に次の送信が行われると考えたためである。 ただし、実際にはそのようになっていない。

5 秒に一度送信が確実にできていれば、1010 秒の 間に 404 回(チャンネル A・B 合わせて)の送信が可能 であるはずであるので、絶対座標送信の成功率は $42.1 \%$ 、相対座標送信の成功率は $81.7 \%$ であ。

相対座標送信は絶対座標計算までに時間差があ るため、位置決定誤差が大きくなる可能性があるが 一方で、送信頻度を高めることができるという点か らは、位置決定誤差を小さくできる可能性がある。

ところで、Fig. 3 および 4 は絶対座標送信と相対 座標送信の送信間隔を秒ごとのヒストグラムとした ものである。双方とも 5 秒に大きな頻度を持ってい るのは、おおむね 5 秒周期での送信タイミングが守 られていることを示している。ただし、バイナリメ ッセージの送信はスロットの空き状況によって最大 4 秒遅れる場合があり、Fig. 3、4 には、頻度は低い ながらも、これによって 5 秒から若干遅れている送 信が存在する。この遅れは位置決定誤差につながる。

また、絶対座標送信では 40 秒付近で、相対座標 送信では 15 秒付近で高頻度の送信があることがわ かる。4.1 節で少しふれたが、これは、タイプ 8 の メッセージの送信はフレーム当たり 20 スロットに 制限されているためである。

今回、絶対座標送信ではメッセージあたり 2 スロ ットとなっており、2 つのチャネルに同時に送信し 


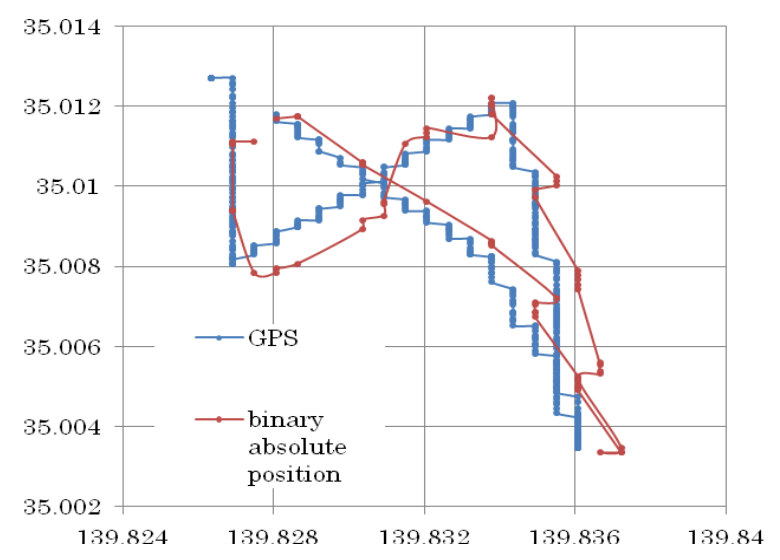

Fig.5 Comparison between transmitted absolute position and GPS position.

ているから、25 秒で 5 メッセージ送信したところで 20 スロットは使い果たしてしまう。また、相対座標 送信ではメッセージあたり 1 スロットであるが、こ れも 50 秒かけて 10 メッセージ送信した段階で 20 スロットを使い果たしてしまう。すると、それぞれ、 1 フレームの間の残り 35 秒、及び、10 秒は送信でき ない時間となり、その時間が過ぎてから次の 5 秒で 送信されるため、40 秒、15 秒の付近に送信が生じる と考えられる。この通信間隔の不均一性はトラッキ ングの精度を損衴るが、今回、実験に際してはこの 事実を把握していなかった。この改善は今後の課題 である。また、本実験において、絶対座標送信およ び相対座標送信におけるフレーム毎の送信可能時間 はそれぞれ約 25 秒、約 50 秒であり、これは 1 フレ 一ム (1 分)のそれぞれ約 $41.7 \%$ 、約 $83.3 \%$ でる。先 に示した送信成功率の $42.1 \% 、 81.7 \%$ は 1 フレームに おける通信可能な時間によってほぼ説明できる。

\section{2 GPS データとの比較}

Fig. 5 および 6 に絶対座標送信と相対座標送信の 航跡とGPSによる航跡の比較を示す。横軸は経度、 縦軸は緯度を示している。GPS 受信機のマニュアル に記載されている測位精度は CEP (50\%) 2.5m（SA 無し)である。補完やスムージングは行っていない。 汐路丸 2 号の走行コースが若干異なるので正確な比 較をすることはできないが、バイナリメッセージ受 信時の GPS 位置に対する二乗差の平均の平方根は絶 対座標送信では $75.2 \mathrm{~m}$ 、相対座標送信では $92.5 \mathrm{~m}$ で あった。

バイナリメッセージの送信可能頻度における比 較では相対座標送信の方が有利であるが、GPS 位置

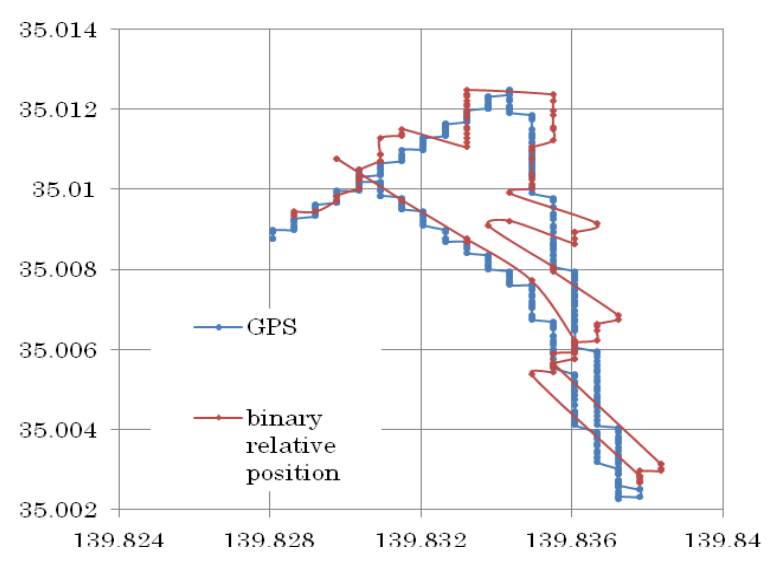

Fig.6 Comparison between transmitted relative position and GPS position.

との平均二乗差における比較では絶対座標送信の方 が有利となっている。

今回、汐路丸は静止した状態であったのでバイナ リメッセージ送信時点での見張り局の位置・船首方 位と、見張り局から発信された最近のタイプ 1 メッ セージで得られた位置・船首方位の差は少ないと考 えられるが、それでも相対座標送信によって誤差は 明らかに増えている。

誤差の原因は、GPS の誤差、レーダー・ARPA の誤 差、バイナリメッセージの送信遅延等々、多数考え られるが、今回のデータだけでは判然としない。2014 年 1 月 21 日は多少の白波が立つ程度に風があり、汐 路丸 2 号をシークラッターの間に捕捉することに難 㗪したが、一度捕捉した後は実験終了までロストす ることはなかった。ただし、ARPA で捕捉している汐 路丸 2 号のマーカーがしばしば跳ねる様子を確認し た。この様子はFig. 5、6 においてバイナリメッセー ジで送信した位置情報が大きく振れていることから も確認できる。これに関して、ARPA でのトラッキン グ中の目標までの計測距離は、見張り局の動摇や風 によるスキャナの振動、クラッターの現れ方によっ て大きく変動すると考えており、また、これが位置 決定誤差の主要因であると考えている。しかしなが ら、様々に考えうる誤差要因の影響を分別するため には、より洗練された実験手順を確立し、多くのデ ータを収集、解析する必要がある。

その上で、双方の位置決定精度を比較するために は、さらにいくつかのステップを経る必要がある。

まず、今回は見張り局を静止させて実験を行った が、これを動かす必要がある。また、位置の決定に はカルマンフィルタ等の手法を用いて適切に平滑化 
する必要がある。

また、バイナリメッセージの送信には RATDMA の 仕様上最大 4 秒の遅延が想定される。位置推定精度 をより高めるためにはUTC 秒を送信データに含め、 計算に用いることが有効であると考えられる。

\section{7. まとめ}

ARPA で捕捉した船舶の情報をAIS バイナリメッセ ージで共有するシステムを開発し、その実験を行っ た。実験では汐路丸から ARPA で捕捉した小型艇・汐 路丸 2 号の位置をバイナリメッセージで送信し、こ れを AIS 受信機で受信することで汐路丸 2 号をトラ ッキングすることが可能であることを示した。

バイナリメッセージの送信方法としては相対座 標送信・絶対座標送信の二通りを試みた。相対座標 送信は送信データが少なく、1 スロットで送信可能 であるため、送信頻度を高めることができるが、一 方で、GPS データとの平均二乗差は絶対座標送信の 方が少ない結果となった。

双方の比較に関しては、今後、誤差の原因の特定 を含めて詳細に行っていく予定である。

一方、見張り局自体の AIS 非搭載船舶の捕捉 - 追 尾・位置決定能力を強化する必要がある。絶対位置 送信における平均 $75 \mathrm{~m}$ の誤差の主要因はARPAの位置 決定誤差であると考えられる。より高度なレーダー およびレーダー信号処理技術、コンピュータビジョ ン等を併用することを計画している。

なお、今回はバイナリメッセージの送信に関する 20 スロット/フレームの制限を認識していなかった ため、5 秒ごとに両方のチャネルで送信したが、今 後は 1 フレームに送信ができるだけ散らばるように 送信したい。さらに情報共有の効率を考慮して、対 象の運動に応じて送信間隔を適切に設定することを 検討したい。

また、今回は、見張り局の船舶 1 隻と見張り対象 となる AIS 非搭載船舶 1 艇という最も単純な構成で 実験を行ったが、現在、複数の見張り局、複数の見 張り対象を扱う場合の通信プロトコルを検討してお り、今後実験によって評価を行いたい。

\section{謝辞}

本研究は東京海洋大学練習船・汐路丸およびその 乗組員の皆さまの協力によって成立しております。 本研究はJSPS 科研費 25820419 の助成を受けたも のです。

\section{参考文献}

(1) ITU : Resolution 360 (WRC-12), 2012.

（2）丹羽康之 - 本木久也 - 西崎ちひろ - 瀬田剛広 : 指向性アンテナを用いた船間無線 LAN 通信実験 -II 行会い状態における実海域実験, 日本航海 学会論文集, Vol.127, pp. 149-155， 2013.

（3）丹羽康之 - 本木久也 - 西崎ちひろ - 瀬田剛広 : 指向性アンテナを用いた船間無線 LAN 通信実験, 日本航海学会論文集，Vo1. 126, pp. 283-288, 2012.

（4）和田雅昭 - 畑中勝守：水産業における情報技術 の活用についてーV. 一マリンブロードバンド の活用一, 日本航海学会論文集, Vol. 122, pp. 53-59, 2010.

（5）和田雅昭 - 畑中勝守 - 佐野稔 - 原田博行：水産 業における情報技術の活用について一VI. 一リ アルタイム情報の活用と水産資源評価一, 日本 航海学会論文集, Vol. 124, pp. 355-362， 2011.

（6）海上保安庁：海難事故の現況と対策について (平成 25 年版)，統計資料，2013，

（7）丹羽康之・福戸淳司 - 宮本佳則 - 稲岡孝：AIS 情 報を用いた小型船用見張り支援システム，日本 航海学会論文集, Vol. 125, pp. 35-43， 2012.

（8）日本無線株式会社：固体素子を用いた $9 \mathrm{GHz}$ 帯 レーダーの研究開発, 総務省, 電波資源活用の ための研究開発，2009.

（9）五十嵐耕：海上保安庁の交通政策について〜海 上交通センター用 $10 \mathrm{GHz}$ 固体化レーダー装置〜， 日本航路標識協会, 第 1 回研究会, 2013.

(10) 松本洋平:HOG 特徵量を用いた船舶画像認識, 日 本航海学会論文集, Vol. 129, pp. 105-112, 2013.

(11) ITU : Recmmendation M. 1371-4, 2010.

(12) IM0 Circular 236: Guidance on the Application of AIS Binary Message, 2004.

(13) IMO Circular 289: Guidance on the Use of AIS Application-Specific Message, 2010.

(14) M. Porthin, R. Zetterberg, S. Sonninen: AIS Binary Messages - Developments in the Baltic and Progress in IMO, $7^{\text {th }}$ IALA Conference, pp. 38-48, 2010.

(15) P. A. McGillivary, K. D. Schwehr, K. Fall: Enhancing AIS to improve whale-ship collision avoidance and maritime security, 
日本航海学会論文集 第131巻 第130回講演会にて講演

Proc. OCEANS, pp. 1-8, 2009. 